\title{
Antigen presentation by mouse monocyte-derived cells : re-evaluating the concept of monocyte-derived dendritic cells
}

\author{
Alice Coillard ${ }^{1,2}$ and Elodie Segura ${ }^{1 *}$ \\ ${ }^{1}$ Institut Curie, PSL Research University, INSERM, U932, 26 rue d'Ulm, 75005 Paris, France \\ ${ }^{2}$ Université Paris Descartes, Paris, France

\section{* Correspondence:} \\ Elodie Segura \\ elodie.segura@curie.fr
}

\begin{abstract}
Antigen presentation is a key feature of classical dendritic cells (cDCs). Numerous studies have also reported in mouse that, upon inflammation, monocytes enter tissues and differentiate into monocyte-derived DCs (mo-DC) that have the ability to present antigens to T cells. However, a population of inflammatory cDCs sharing phenotypic features with moDC has been recently described, challenging the existence of in vivo-generated mo-DC. Here we review studies describing mouse mo-DC in the light of these findings, and evaluate the in vivo evidence for monocyte-derived antigen-presenting cells. We examine the strategies used to demonstrate the monocytic origin of these cells. Finally, we propose that mo-DC play a complementary role to cDCs, by presenting antigens to effector T cells locally in tissues.
\end{abstract}

\section{Keywords}

Dendritic cell, monocyte, monocyte-derived dendritic cell, antigen presentation, inflammation 


\section{Introduction}

Characteristic features of dendritic cells (DCs) include their ability to present exogenous antigens on MHC molecules and to activate naive T cells. Numerous studies have shown that DCs can be separated into 3 main subsets based on their phenotype and molecular ontogeny: plasmacytoid DCs, type 1 classical DCs (cDC1) and type 2 classical DCs (cDC2) (Guilliams et al., 2014). All three subsets depend on the growth factor Fms-like tyrosine kinase 3-ligand (Flt3-L) and can be derived from a committed common DC precursor (CDP) (Naik et al., 2007). An additional population of antigen-presenting cells has been identified in mouse models of infection and sterile inflammation (Kool et al., 2008; León et al., 2007). These cells were demonstrated to originate from monocytes using adoptive cell transfer, and were termed monocyte-derived DCs (mo-DCs) owing to their DC-like ability to present antigens and to stimulate T cells. Mo-DCs, characterized by their expression of CD11b, Ly6C and/or CD64, were subsequently reported in other inflammatory contexts, as well as in steady-state mucosal tissues (Bonnardel et al., 2015; Tamoutounour et al., 2013) and peritoneal cavity (Goudot et al., 2017). Despite obvious methodological limitations, equivalent mo-DCs were also identified in human tissues (Coillard and Segura, 2019). However, recent findings showing that mouse cDC2 upregulate Ly6C and CD64 during inflammation (Bosteels et al., 2020; Min et al., 2018) have challenged the concept of monocyte-derived cells capable of antigen presentation.

In this review, we re-examine the published literature on mouse mo-DCs in light of these findings, and evaluate whether there is sufficient evidence to support the existence of bona fide antigen-presenting cells derived from monocytes.

\section{Comparative features of mo-DCs and $\mathrm{CD}^{+} 4^{+} \mathrm{cDC} 2$}

Mo-DCs have been described in peripheral tissues as well as in inflamed lymphoid organs. They are usually characterized by the surface expression of CD11c, MHCII, CD11b, 
Ly6C, CD64, and have also been shown to express F4/80, CD115, CD206 and CCR2. Their monocytic origin has been documented using adoptive transfer of purified monocytes or depletion of monocytes using clodronate liposomes, which deplete monocytes and macrophages but not cDCs (Leenen et al., 1998). Using deficient mice or bone marrow chimeras, their differentiation was shown to require CCR2, a chemokine receptor essential for monocyte migration from the bone marrow (Serbina and Pamer, 2006; Tsou et al., 2007). Their ontogeny has also been indirectly addressed by showing their independence on Flt3-L.

'Inflammatory' cDC2 have been described in lung and lung-draining lymph nodes during inflammation, but are absent in the steady-state (Bosteels et al., 2020). They express surface molecules previously thought to be specific mo-DC markers such as Ly6C, CD64, MAR1 and CD209a. However, they do not express CCR2, CD115 or F4/80. They also upregulate IRF8, a transcription factor highly expressed in steady-state cDC1. This phenotype is induced in $\mathrm{cDC} 2$ by exposure to type $\mathrm{I}$ interferon. Their $\mathrm{cDC}$ identity has been demonstrated by adoptive transfer of pre-cDC and dependence on Flt3-L. Consistent with this, they express high amounts of Zbtb46, a transcription factor specifically expressed in cDCs (Meredith et al., 2012; Satpathy et al., 2012). Importantly, their presence in inflamed tissues, but not in lymphoid organs, was shown to be partially dependent on CCR2 in a mixed bone marrow experiment. Of note, $\mathrm{CD}^{+} 4^{+} \mathrm{cDCs}$ have also been reported in steady-state kidney (Schraml et al., 2013). Kidney $\mathrm{CD}^{+} 4^{+} \mathrm{MHCII}^{+} \mathrm{CD}_{11 \mathrm{~b}^{+}} \mathrm{F} 4 / 80^{\text {low }}$ cells display functional and transcriptomic similarities with cDC2 (Salei et al., 2020). Their cDC identity was demonstrated using genetic lineage tracing and adoptive transfer of CDP (Schraml et al., 2013), and dependence on Flt3-L (Guilliams et al., 2016).

Overall, these observations indicate that the phenotypic markers previously used to identify mo-DCs cannot distinguish them from $\mathrm{CD}^{+} 4^{+} \mathrm{cDC} 2$. $\mathrm{cDCs}$ can be separated from monocyte-derived cells by the expression of CD26 (Bosteels et al., 2020; Guilliams et al., 2016), but this marker has not been extensively used so far. Because DC precursors 
transiently express the monocyte genes CD115, CCR2 and CX3CR1, strategies based on these fluorescent reporters to track monocytes and their progeny can also be misleading if not carefully controlled, as peripheral cDCs display some level of fluorescence (Hohl et al., 2009; Jung et al., 2000; MacDonald et al., 2005; Satpathy et al., 2013). In addition, because both mo-DCs and $\mathrm{CD}^{+} 4^{+}$DCs are decreased in the peripheral tissues of CCR2 $2^{-/-}$mice, results obtained using this approach cannot be considered an absolute proof of monocyte origin. Therefore, we argue that, in the absence of CD26 staining, true mo-DCs can only be reliably identified in the published literature when their origin has been specifically probed, in particular using adoptive transfer or targeted depletion of monocytes.

\section{Evidence for antigen presentation by in vivo-generated monocyte-derived cells}

The initial observation that monocytes can differentiate into DC-like cells was made in a model of Leishmania major infection (León et al., 2007). Adoptive transfer of monocytes showed that they upregulate DC markers CD11c and MHCII upon entry into inflamed skin or lymph nodes. Two populations of CD11b ${ }^{+}$'inflammatory' DCs were identified, F4/80 ${ }^{\text {high }}$ Ly6C $^{\text {high }}$ and F4/80'Ly6C ${ }^{\text {int }}$, likely corresponding to monocyte-derived cells and CD64 ${ }^{+}$cDC2 respectively. Because both populations were pooled for antigen presentation experiments in this study, it is not possible to conclude whether monocyte-derived cells are indeed antigenpresenting cells.

Subsequently, a number of studies have analyzed antigen presentation by putative moDCs, but using strategies that we now know cannot separate them from contaminating cDC2 (Table). Conclusions from these studies will need to be confirmed with more appropriate methods to evaluate the respective contributions of mo-DCs and $\mathrm{CD} 64^{+} \mathrm{cDC} 2$.

However, other studies have provided formal evidence that monocyte-derived cells are capable of antigen presentation. In a model of sterile inflammation, DC depletion after 
Diphteria Toxin (DT) injection in CD11c-DTR mice abrogated CD4 T cell activation (Kool et al., 2008). It could be restored after adoptive transfer of monocytes, showing that monocytederived cells were capable of antigen presentation on MHC class II molecules and CD4 T cell stimulation. In a model of local viral reactivation, recruited DCs stimulated resident memory CD8 and CD4 T cells, which was dependent on MHC expression by the DCs indicating bona fide antigen presentation (Wakim et al., 2008). Recruited DCs were strongly decreased by injection of clodronate liposomes. Therefore, these observations show that mo-DCs present the viral antigens to resident $\mathrm{T}$ cells after virus reactivation. In a Salmonella typhimurium infection model, clodronate liposomes injection also decreased the activation of CD4 T cells in infected spleens, indicating antigen presentation by mo-DCs (Flores-Langarica et al., 2011).

Two other studies support the identification of antigen-presenting monocyte-derived cells in inflammed tissues, although their cellular ontogeny will need to be further confirmed. In experimental autoimmune encephalomyelitis, stainings with an antibody specific for peptide-MHC class I complexes identified a population of antigen-presenting DCs in the central nervous system displaying a mo-DC phenotype (Ji et al., 2013). Although complementary experiments were not performed to address the ontogeny of these cells, their characterization as $\mathrm{CD} 11 \mathrm{~b}^{+} \mathrm{Ly} 6 \mathrm{C}^{+} \mathrm{F} 4 / 80^{+} \mathrm{CCR} 2^{+} \mathrm{DCs}$ with low expression of Irf8 and Zbtb46 strongly suggests that they are mo-DCs, rather than 'inflammatory' cDC2. In a colitis model,

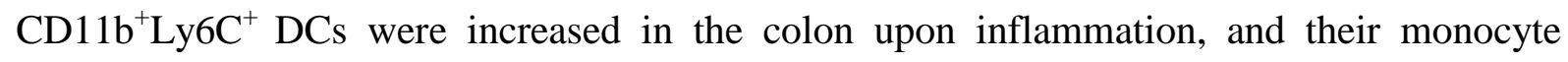
origin was evidenced using adoptive transfer and lack of Zbtb46 expression (Zigmond et al., 2012). After gavage with a model antigen, these cells could stimulate antigen-specific CD4 T cells ex vivo, indicating their ability to present antigens on their MHC class II molecules. Of note, mo-DCs were less efficient for $\mathrm{T}$ cell stimulation than CCR2-dependent CD11b ${ }^{+}$Ly6C ${ }^{\text {low }}$ DCs, which were likely ‘inflammatory’ cDC2. 
Monocytes are also known to infiltrate tumors and several studies have identified populations of mo-DCs after immunostimulatory treatments. CD $11 \mathrm{~b}^{+} \mathrm{CD} 64^{+} \mathrm{Ly} 6 \mathrm{C}^{+}$DCs were increased in the draining lymph nodes of tumor-bearing mice that were locally treated with a combination of monosodium urate crystals and Mycobacterium smegmatis (Kuhn et al., 2015). Adoptively transferred monocytes were recruited to tumor-draining lymph nodes of treated mice and adopted this phenotype, showing that at least a portion of these cells could derive from monocytes. The accumulation in the tumor of antigen-specific CD8 T cell was abrogated upon DC depletion in CD11c-DTR bone marrow chimeric mice, however it was restored upon transfer of monocytes. This observation confirms that monocyte-derived cells were capable of presenting tumor antigens to $\mathrm{T}$ cells. Treatment of tumor-bearing mice with chemotherapy also favored the appearance in the tumor of a population of $\mathrm{CD}_{11} \mathrm{~b}^{+} \mathrm{Ly} 6 \mathrm{C}^{+}$ DCs also expressing CD103 and CCR2 (Ma et al., 2013; Sharma et al., 2018). Adoptive transfer experiments showed that these cells did not differentiate from CDP, but derived from monocytic precursors (Ma et al., 2013; Sharma et al., 2018). These mo-DCs could stimulate efficienly antigen-specific CD8 T cells ex vivo, showing they had captured and presented tumor antigens on their MHC class I molecules (Ma et al., 2013; Sharma et al., 2018).

Finally, antigen presentation is not limited to 'inflammatory' mo-DCs and can also be performed by mucosol mo-DCs. Because they differentiate in the steady-state, these mo-DC populations are easily distinguished from $\mathrm{CDC} 2$ based on their phenotype and dependence on CCR2. Skin mo-DCs could present a model antigen to CD4 and CD8 T cells when cultured in vitro, although less efficiently than cDCs (Tamoutounour et al., 2013). Similarly, mo-DCs from Peyer's patches were capable of antigen presentation to CD4 T cells in vitro (Bonnardel et al., 2015), and were observed interacting with CD4 T cells in situ by microscopy (Wagner et al., 2020).

\section{Complementary roles for mo-DCs and cDCs in $\mathrm{T}$ cell activation}


A characteristic feature of DCs is their ability to migrate from peripheral tissues to draining lymph nodes where the activation of naïve $\mathrm{T}$ cells takes place. However, monocytederived cells have been shown to have a low migratory capacity. In a model of lung inflammation, $\mathrm{CD} 11 \mathrm{~b}^{+} \mathrm{Ly} 6 \mathrm{C}^{+} \mathrm{CD} 14^{+}$DCs were non-migratory and lacked expression of CCR7, a chemokine receptor required for DC migration to lymph nodes (Nakano et al., 2013). Their monocyte origin was confirmed by adoptive transfer and independence on Flt3-L (Nakano et al., 2013). In a model of lung infection, only $\mathrm{CD} 26^{+} \mathrm{CD} 11 \mathrm{~b}^{+} \mathrm{CD} 64^{+} \mathrm{cDC} 2$ were found in draining lymph nodes, while monocyte-derived cells did not migrate (Bosteels et al., 2020). Consistent with this, other studies in which mo-DCs and 'inflammatory' $\mathrm{CD}^{+} 4^{+} \mathrm{cDC} 2$ cannot be formally distinguished have reported a lack of detection or low numbers of these cells in draining lymph nodes (Aldridge et al., 2009; Langlet et al., 2012; Lim et al., 2020; Plantinga et al., 2013). Of note, putative mo-DCs have been observed in lymphoid organs, but lack of CCR7 expression or independence on CCR7 suggests that these cells originated from monocytes directly recruited from blood to inflamed lymph nodes, rather than from migratory mo-DCs (Langlet et al., 2012; Nakano et al., 2013, 2009). Supporting this idea, monocytes have been shown to enter lymph nodes through the high endothelial venules during adjuvantinduced inflammation (Leal et al., 2021; Palframan et al., 2001).

The efficient activation of effector $\mathrm{T}$ cells requires interactions between antigenpresenting cells and $\mathrm{T}$ cells in peripheral tissues, which provides signals to maintain their polarisation and effector functions (Honda et al., 2014; Ley, 2014; Natsuaki et al., 2014; Veres et al., 2017). Several lines of evidence support a role for mo-DCs in this process through the presentation of antigens directly in inflamed tissues. In tumor-bearing mice treated with chemotherapy, surgical removal of draining lymph nodes did not abolish CD8 T cells activation in the tumor, indicating that antigen presentation occurred in situ (Ma et al., 2013). Mo-DCs were identified as the antigen-presenting cells in the tumor (Ma et al., 2013). Consistent with these findings, cognate interactions between $\mathrm{CD} 11 \mathrm{~b}^{+} \mathrm{Ly}_{6 \mathrm{C}}{ }^{+} \mathrm{DCs}$ and $\mathrm{T}$ cells 
have been observed by imaging in inflamed tissues in models of lung infection (Lim et al., 2020) and kidney allograft (Zhuang et al., 2016). In addition, in a model of vaginal infection, CCR2-dependent DCs were dispensable for priming CD4 T cells but were involved in the in situ restimulation of effector T cells (Iijima et al., 2011). Finally, this peripheral antigen presentation can also be involved in the activation of autoreactive $\mathrm{T}$ cells, as shown in models of multiple sclerosis (Greter et al., 2005; Kivisäkk et al., 2009; Odoardi et al., 2007). In this setting, although antigen presentation was not directly addressed, mo-DCs but not cDCs were shown to be responsible for pathogenic CD4 T cells activation (Croxford et al., 2015).

Local antigen presentation by mo-DCs can also allow the activation of tissue-resident memory $\mathrm{T}$ cells, as shown in experimental virus reactivation (Wakim et al., 2008). In this model, herpes simplex virus was reactivated upon transplantation into a naïve mouse of peripheral tissues of a previously infected mouse. Virus-specific donor CD4 and CD8 T cells both proliferated locally and were not found recirculating in the host mouse. This phenomenon was dependent on recruited host mo-DCs (Wakim et al., 2008).

Collectively, these observations support a model in which migratory cDCs and nonmigratory mo-DCs play complementary roles for the optimal induction of adaptive immune responses (figure). While cDCs transport antigens to draining lymph nodes to prime naïve T cells, mo-DCs would present antigens in tissues to boost effector functions of newly recruited $\mathrm{T}$ cells or to rapidly activate tissue-resident memory $\mathrm{T}$ cells.

\section{Conclusion and perspectives}

The recent description of inflammatory $\mathrm{cDC} 2$ challenged the existence of antigen-presenting cells derived from monocytes. These inflammatory cDC2 express numerous markers previously used to identify mo-DC and are partially dependent on CCR2. Therefore, these two strategies are no longer sufficient to assign a mo-DC identity. Nevertheless, we argue that studies based on monocyte depletion or adoptive transfer of monocytes have demonstrated the 
presence in tissues of bona fide antigen-presenting cells derived from monocytes. These cells do not migrate to lymph nodes and can present antigens to effector T cells directly in tissues. Collectively, the work discussed here supports a model in which cDCs and mo-DC play complementary roles for the optimal induction of $\mathrm{T}$ cell responses, by presenting antigens in lymphoid organs or inflamed tissues respectively.

More work is needed to re-evaluate the contribution of mo-DC to antigen presentation, in particular in fungal infections, chronic inflammatory diseases and allograft rejection. In the absence of unique markers for mo-DC, the minimal set of phenotypic markers should include CD26 to distinguish cDC2 from mo-DC. New fate-mapping models will also be useful to track monocyte-derived cells in a more specific way, such as the Ms4a3 reporter mouse (Liu et al., 2019).

Finally, future studies should aim at translating these findings to human. Numerous studies have provided evidence for the in vivo differentiation of mo-DCs in human (Coillard and Segura, 2019). However, inflammatory cDC2 have not been identified in clinical samples yet. In addition, a population displaying mixed features of monocytes and DCs has been recently characterized in human, termed DC3 (Villar and Segura, 2020). How this population relates to mo-DC remains to be investigated. Addressing these questions will be essential for deciphering the role of mo-DC in the context of cancer or chronic inflammatory diseases. 


\section{Author Contributions}

$\mathrm{AC}$ and ES wrote the manuscript.

\section{Acknowledgements}

This work was funded by INSERM and Agence Nationale de la Recherche (ANR-10-LABX0043 and ANR-17-CE15-0011-01).

\section{Competing interests statement}

The authors declare no competing interests. 


\section{Figure Legend}

\section{Proposed model of the respective roles of classical DCs and monocyte-derived DCs in T}

cell stimulation. Upon inflammation, classical DC1, classical DC2 and inflammatory classical DC2 migrate to lymph nodes, where they present antigens to naive $\mathrm{T}$ cells. In parallel, monocytes enter inflamed tissues and differentiate into monocyte-derived DCs that further stimulate effector $\mathrm{T}$ cells. Thick and thin arrows represent differentiation and migration respectively. moDC, monocyte-derived DCs; cDC1, classical DC1; cDC2, classical DC2; inf cDC2, inflammatory classical DC2.

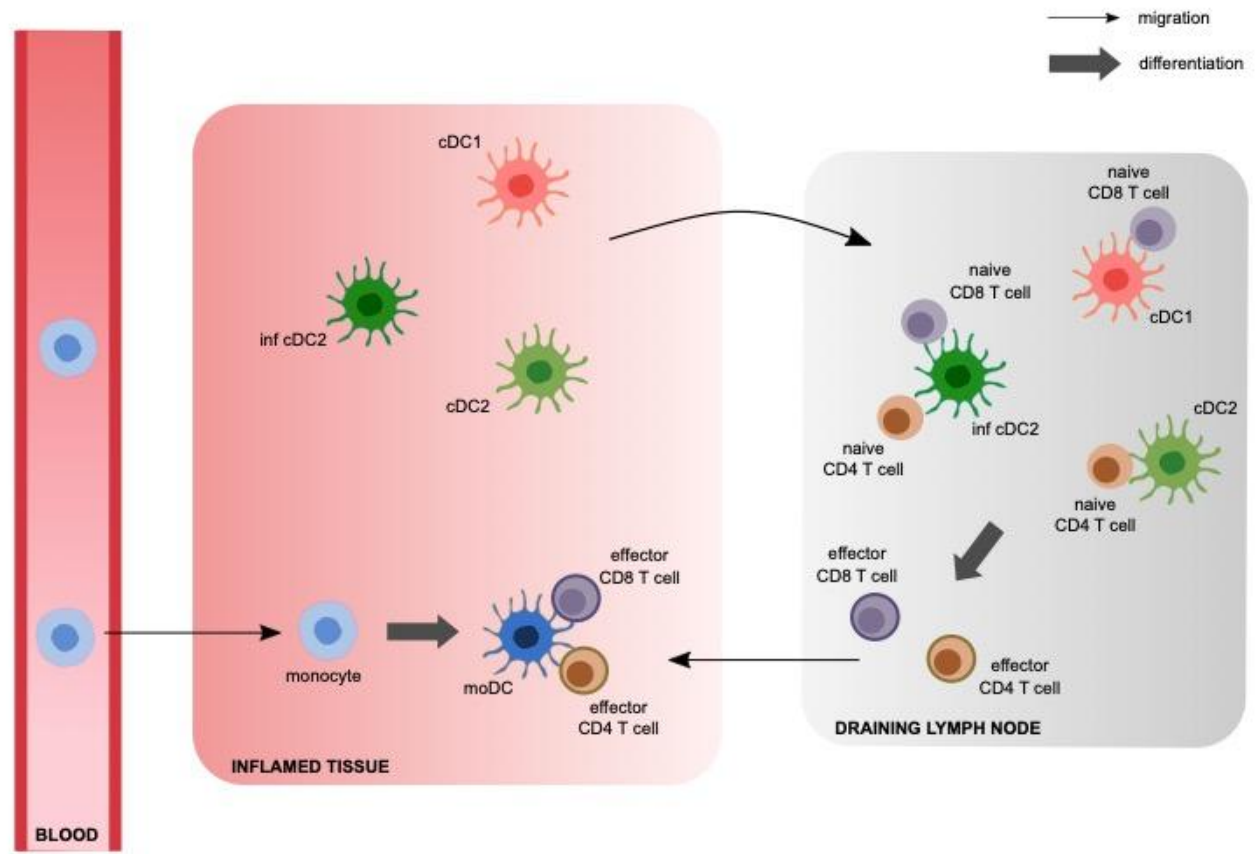


Table. Studies in which antigen-presenting cells cannot be resolved between mo-DCs and $\mathrm{CD}^{+} 4^{+} \mathrm{cDC} 2$

\begin{tabular}{|c|c|c|c|}
\hline Reference & Context & Experimental strategy & $\begin{array}{l}\text { Type of Antigen } \\
\text { presentation }\end{array}$ \\
\hline $\begin{array}{l}\text { (Aldridge et } \\
\text { al., 2009) }\end{array}$ & Viral infection & Isolation of CD11 $\mathrm{b}^{+} \mathrm{Ly} 6 \mathrm{C}^{+} \mathrm{DCs}$ & $\begin{array}{l}\text { Cross- } \\
\text { presentation }\end{array}$ \\
\hline $\begin{array}{l}\text { (Bedford et al., } \\
\text { 2020) }\end{array}$ & $\begin{array}{l}\text { Viral and } \\
\text { bacteria infection }\end{array}$ & $\begin{array}{l}\text { Isolation of } \mathrm{CD} 11 \mathrm{~b}^{+} \mathrm{CD} 64^{+} \mathrm{MAR} 1^{+} \\
\text {DCs }\end{array}$ & $\begin{array}{l}\text { Cross- } \\
\text { presentation }\end{array}$ \\
\hline $\begin{array}{l}\text { (Chakarov and } \\
\text { Fazilleau, } \\
\text { 2014) }\end{array}$ & $\begin{array}{l}\text { Adjuvanted } \\
\text { vaccination }\end{array}$ & $\begin{array}{l}\text { Detection of peptide-MHC } \\
\text { complexes by flow cytometry (gated } \\
\text { on } \mathrm{CD} 11 \mathrm{~b}^{+} \mathrm{CD} 64^{+} \mathrm{DCs} \text { ) }\end{array}$ & $\begin{array}{l}\text { MHC } \\
\text { presentation }\end{array}$ \\
\hline $\begin{array}{l}\text { (Chang et al., } \\
\text { 2017) }\end{array}$ & $\begin{array}{l}\text { Chronic viral } \\
\text { infection }\end{array}$ & $\begin{array}{l}\text { Isolation of } \mathrm{CD} 11 \mathrm{~b}^{+} \mathrm{CD}^{+} 4^{+} \mathrm{MAR}-1^{+} \\
\text {DCs }\end{array}$ & $\begin{array}{l}\text { MHC } \\
\text { presentation }\end{array}$ \\
\hline $\begin{array}{l}\text { (Hohl et al., } \\
\text { 2009) }\end{array}$ & $\begin{array}{l}\text { Fungal and } \\
\text { bacteria infection }\end{array}$ & In vivo depletion in $C c r 2$-DTR mice & $\begin{array}{l}\text { MHC } \\
\text { presentation }\end{array}$ \\
\hline $\begin{array}{l}\text { (Iijima et al., } \\
\text { 2011) }\end{array}$ & Viral infection & $\begin{array}{l}\text { CCR2 KO mice in vivo and isolation } \\
\text { of } \mathrm{CD} 11 \mathrm{c}^{+} \mathrm{CD} 11 \mathrm{~b}^{+} \mathrm{DCs}\end{array}$ & $\begin{array}{l}\text { MHC } \\
\text { presentation }\end{array}$ \\
\hline $\begin{array}{l}\text { (Ko et al., } \\
2014)\end{array}$ & $\begin{array}{l}\text { Inflammatory } \\
\text { disease (EAE) } \\
\text { Bacteria and } \\
\text { parasite infection }\end{array}$ & Isolation of $\mathrm{CD}_{11 \mathrm{~b}^{+} \mathrm{Ly} 6 \mathrm{C}^{+} \mathrm{DCs}}$ & $\begin{array}{l}\text { MHC } \\
\text { presentation }\end{array}$ \\
\hline $\begin{array}{l}\text { (Langlet et al., } \\
\text { 2012) }\end{array}$ & $\begin{array}{l}\text { Sterile } \\
\text { inflammation }\end{array}$ & $\begin{array}{l}\text { Isolation of } \mathrm{CD} 11 \mathrm{~b}^{+} \mathrm{CD} 64^{+} \mathrm{Ly} 6 \mathrm{C}^{+} \\
\mathrm{DCs}\end{array}$ & $\begin{array}{l}\text { Cross- } \\
\text { presentation } \\
\text { MHC }\end{array}$ \\
\hline
\end{tabular}




\begin{tabular}{|c|c|c|c|c|}
\hline & & & presentation & \\
\hline $\begin{array}{l}\text { (León et al., } \\
\text { 2007) }\end{array}$ & Parasite infection & Isolation of CD11 $\mathrm{b}^{+} \mathrm{Ly} 6 \mathrm{C}^{+} \mathrm{DCs}$ & $\begin{array}{l}\text { MHC } \\
\text { presentation }\end{array}$ & II \\
\hline $\begin{array}{l}\text { (Lim et al., } \\
2020)\end{array}$ & Viral infection & $\begin{array}{l}\text { Imaging in } C s f 1 r \text {-EGFP reporter } \\
\text { mouse }\end{array}$ & $\begin{array}{l}\text { Cross- } \\
\text { presentation }\end{array}$ & \\
\hline $\begin{array}{l}\text { (Nakano et al., } \\
\text { 2009) }\end{array}$ & Viral infection & Isolation of CD11 $\mathrm{b}^{+} \mathrm{Ly} 6 \mathrm{C}^{+} \mathrm{DCs}$ & $\begin{array}{l}\text { MHC } \\
\text { presentation }\end{array}$ & II \\
\hline $\begin{array}{l}\text { (Plantinga et } \\
\text { al., 2013) }\end{array}$ & $\begin{array}{l}\text { House Dust Mite } \\
\text { Allergy }\end{array}$ & $\begin{array}{l}\text { Isolation of } \mathrm{CD} 11 \mathrm{~b}^{+} \mathrm{Mar1}^{+} \mathrm{CD}^{+} 4^{+} \\
\text {DCs }\end{array}$ & $\begin{array}{l}\text { MHC } \\
\text { presentation }\end{array}$ & II \\
\hline $\begin{array}{l}\text { (Segura et al., } \\
2009)\end{array}$ & $\begin{array}{l}\text { Sterile } \\
\text { inflammation }\end{array}$ & Isolation of CD11 b ${ }^{+} \mathrm{Ly} \mathrm{C}^{+} \mathrm{DCs}$ & $\begin{array}{l}\text { Cross- } \\
\text { presentation } \\
\text { MHC } \\
\text { presentation }\end{array}$ & II \\
\hline $\begin{array}{l}\text { (Zhuang et al., } \\
\text { 2016) }\end{array}$ & Allograft & $\begin{array}{l}\text { Imaging in } C \times 3 c r l-G F P \text { reporter } \\
\text { mouse } \\
\text { Isolation of } \mathrm{CD} 11 \mathrm{~b}^{+} \mathrm{DCs}\end{array}$ & $\begin{array}{l}\text { Cross- } \\
\text { presentation } \\
\text { MHC } \\
\text { presentation }\end{array}$ & II \\
\hline
\end{tabular}




\section{References}

Aldridge, J.R., Moseley, C.E., Boltz, D.A., Negovetich, N.J., Reynolds, C., Franks, J., Brown, S.A., Doherty, P.C., Webster, R.G., Thomas, P.G., 2009. TNF/iNOS-producing dendritic cells are the necessary evil of lethal influenza virus infection. Proc. Natl. Acad. Sci. USA 106, 5306-5311. doi:10.1073/pnas.0900655106

Bedford, J.G., Heinlein, M., Garnham, A.L., Nguyen, T.H.O., Loudovaris, T., Ge, C., Mannering, S.I., Elliott, M., Tangye, S.G., Kedzierska, K., Gray, D.H.D., Heath, W.R., Wakim, L.M., 2020. Unresponsiveness to inhaled antigen is governed by conventional dendritic cells and overridden during infection by monocytes. Sci. Immunol. 5, eabb5439. doi:10.1126/sciimmunol.abb5439

Bonnardel, J., Da Silva, C., Henri, S., Tamoutounour, S., Chasson, L., Montañana-Sanchis, F., Gorvel, J.-P., Lelouard, H., 2015. Innate and adaptive immune functions of peyer's patch monocyte-derived cells. Cell Rep. 11, 770-784. doi:10.1016/j.celrep.2015.03.067

Bosteels, C., Neyt, K., Vanheerswynghels, M., van Helden, M.J., Sichien, D., Debeuf, N., De Prijck, S., Bosteels, V., Vandamme, N., Martens, L., Saeys, Y., Louagie, E., Lesage, M., Williams, D.L., Tang, S.C., Mayer, J.U., Ronchese, F., Scott, C.L., Hammad, H., Guilliams, M., Lambrecht, B.N., 2020. Inflammatory Type 2 cDCs Acquire Features of $\mathrm{cDC} 1 \mathrm{~s}$ and Macrophages to Orchestrate Immunity to Respiratory Virus Infection. Immunity 52, 1039-1056.e9. doi:10.1016/j.immuni.2020.04.005

Chakarov, S., Fazilleau, N., 2014. Monocyte-derived dendritic cells promote T follicular helper cell differentiation. EMBO Mol. Med. 6, 590-603. doi:10.1002/emmm.201403841

Chang, Y.-H., Wang, K.C., Chu, K.-L., Clouthier, D.L., Tran, A.T., Torres Perez, M.S., Zhou, A.C., Abdul-Sater, A.A., Watts, T.H., 2017. Dichotomous Expression of TNF Superfamily Ligands on Antigen-Presenting Cells Controls Post-priming Anti-viral CD4+ T Cell Immunity. Immunity 47, 943-958.e9. doi:10.1016/j.immuni.2017.10.014

Coillard, A., Segura, E., 2019. In vivo Differentiation of Human Monocytes. Front. Immunol. 10, 1907. doi:10.3389/fimmu.2019.01907

Croxford, A.L., Lanzinger, M., Hartmann, F.J., Schreiner, B., Mair, F., Pelczar, P., Clausen, B.E., Jung, S., Greter, M., Becher, B., 2015. The Cytokine GM-CSF Drives the Inflammatory Signature of CCR2+ Monocytes and Licenses Autoimmunity. Immunity 43, 502-514. doi:10.1016/j.immuni.2015.08.010

Flores-Langarica, A., Marshall, J.L., Bobat, S., Mohr, E., Hitchcock, J., Ross, E.A., Coughlan, R.E., Khan, M., Van Rooijen, N., Henderson, I.R., Maclennan, I.C.M., Cunningham, A.F., 2011. T-zone localized monocyte-derived dendritic cells promote Th1 priming to Salmonella. Eur. J. Immunol. 41, 2654-2665. doi:10.1002/eji.201141440

Goudot, C., Coillard, A., Villani, A.-C., Gueguen, P., Cros, A., Sarkizova, S., Tang-Huau, T.L., Bohec, M., Baulande, S., Hacohen, N., Amigorena, S., Segura, E., 2017. Aryl Hydrocarbon Receptor Controls Monocyte Differentiation into Dendritic Cells versus Macrophages. Immunity 47, 582-596.e6. doi:10.1016/j.immuni.2017.08.016

Greter, M., Heppner, F.L., Lemos, M.P., Odermatt, B.M., Goebels, N., Laufer, T., Noelle, R.J., Becher, B., 2005. Dendritic cells permit immune invasion of the CNS in an animal model of multiple sclerosis. Nat. Med. 11, 328-334. doi:10.1038/nm1197

Guilliams, M., Dutertre, C.-A., Scott, C.L., McGovern, N., Sichien, D., Chakarov, S., Van Gassen, S., Chen, J., Poidinger, M., De Prijck, S., Tavernier, S.J., Low, I., Irac, S.E., Mattar, C.N., Sumatoh, H.R., Low, G.H.L., Chung, T.J.K., Chan, D.K.H., Tan, K.K., Hon, T.L.K., Fossum, E., Bogen, B., Choolani, M., Chan, J.K.Y., Larbi, A., Luche, H., 
Henri, S., Saeys, Y., Newell, E.W., Lambrecht, B.N., Malissen, B., Ginhoux, F., 2016. Unsupervised High-Dimensional Analysis Aligns Dendritic Cells across Tissues and Species. Immunity 45, 669-684. doi:10.1016/j.immuni.2016.08.015

Guilliams, M., Ginhoux, F., Jakubzick, C., Naik, S.H., Onai, N., Schraml, B.U., Segura, E., Tussiwand, R., Yona, S., 2014. Dendritic cells, monocytes and macrophages: a unified nomenclature based on ontogeny. Nat. Rev. Immunol. 14, 571-578. doi: $10.1038 /$ nri3712

Hohl, T.M., Rivera, A., Lipuma, L., Gallegos, A., Shi, C., Mack, M., Pamer, E.G., 2009. Inflammatory monocytes facilitate adaptive CD4 $\mathrm{T}$ cell responses during respiratory fungal infection. Cell Host Microbe 6, 470-481. doi:10.1016/j.chom.2009.10.007

Honda, T., Egen, J.G., Lämmermann, T., Kastenmüller, W., Torabi-Parizi, P., Germain, R.N., 2014. Tuning of antigen sensitivity by T cell receptor-dependent negative feedback controls T cell effector function in inflamed tissues. Immunity 40, 235-247. doi:10.1016/j.immuni.2013.11.017

Iijima, N., Mattei, L.M., Iwasaki, A., 2011. Recruited inflammatory monocytes stimulate antiviral Th1 immunity in infected tissue. Proc. Natl. Acad. Sci. USA 108, 284-289. doi:10.1073/pnas.1005201108

Ji, Q., Castelli, L., Goverman, J.M., 2013. MHC class I-restricted myelin epitopes are crosspresented by Tip-DCs that promote determinant spreading to $\mathrm{CD}^{+} \mathrm{T}$ cells. Nat. Immunol. 14, 254-261. doi:10.1038/ni.2513

Jung, S., Aliberti, J., Graemmel, P., Sunshine, M.J., Kreutzberg, G.W., Sher, A., Littman, D.R., 2000. Analysis of fractalkine receptor CX(3)CR1 function by targeted deletion and green fluorescent protein reporter gene insertion. Mol. Cell. Biol. 20, 4106-4114. doi:10.1128/mcb.20.11.4106-4114.2000

Kivisäkk, P., Imitola, J., Rasmussen, S., Elyaman, W., Zhu, B., Ransohoff, R.M., Khoury, S.J., 2009. Localizing central nervous system immune surveillance: meningeal antigen-presenting cells activate $\mathrm{T}$ cells during experimental autoimmune encephalomyelitis. Ann. Neurol. 65, 457-469. doi:10.1002/ana.21379

Ko, H.-J., Brady, J.L., Ryg-Cornejo, V., Hansen, D.S., Vremec, D., Shortman, K., Zhan, Y., Lew, A.M., 2014. GM-CSF-responsive monocyte-derived dendritic cells are pivotal in Th17 pathogenesis. J. Immunol. 192, 2202-2209. doi:10.4049/jimmunol.1302040

Kool, M., Soullié, T., van Nimwegen, M., Willart, M.A.M., Muskens, F., Jung, S., Hoogsteden, H.C., Hammad, H., Lambrecht, B.N., 2008. Alum adjuvant boosts adaptive immunity by inducing uric acid and activating inflammatory dendritic cells. J. Exp. Med. 205, 869-882. doi:10.1084/jem.20071087

Kuhn, S., Yang, J., Ronchese, F., 2015. Monocyte-Derived Dendritic Cells Are Essential for CD8(+) T Cell Activation and Antitumor Responses After Local Immunotherapy. Front. Immunol. 6, 584. doi:10.3389/fimmu.2015.00584

Langlet, C., Tamoutounour, S., Henri, S., Luche, H., Ardouin, L., Grégoire, C., Malissen, B., Guilliams, M., 2012. CD64 expression distinguishes monocyte-derived and conventional dendritic cells and reveals their distinct role during intramuscular immunization. J. Immunol. 188, 1751-1760. doi:10.4049/jimmunol.1102744

Leal, J.M., Huang, J.Y., Kohli, K., Stoltzfus, C., Lyons-Cohen, M.R., Olin, B.E., Gale, M., Gerner, M.Y., 2021. Innate cell microenvironments in lymph nodes shape the generation of T cell responses during type I inflammation. Sci. Immunol. 6. doi:10.1126/sciimmunol.abb9435

Leenen, P.J., Radosević, K., Voerman, J.S., Salomon, B., van Rooijen, N., Klatzmann, D., van Ewijk, W., 1998. Heterogeneity of mouse spleen dendritic cells: in vivo phagocytic activity, expression of macrophage markers, and subpopulation turnover. J. Immunol. 160, 2166-2173.

León, B., López-Bravo, M., Ardavín, C., 2007. Monocyte-derived dendritic cells formed at 
the infection site control the induction of protective $\mathrm{T}$ helper 1 responses against Leishmania. Immunity 26, 519-531. doi:10.1016/j.immuni.2007.01.017

Ley, K., 2014. The second touch hypothesis: T cell activation, homing and polarization. [version 2; peer review: 2 approved, 2 approved with reservations]. F1000Res. 3, 37. doi:10.12688/f1000research.3-37.v2

Lim, K., Kim, T.-H., Trzeciak, A., Amitrano, A.M., Reilly, E.C., Prizant, H., Fowell, D.J., Topham, D.J., Kim, M., 2020. In situ neutrophil efferocytosis shapes T cell immunity to influenza infection. Nat. Immunol. 21, 1046-1057. doi:10.1038/s41590-020-0746-X Liu, Zhaoyuan, Gu, Y., Chakarov, S., Bleriot, C., Kwok, I., Chen, X., Shin, A., Huang, W., Dress, R.J., Dutertre, C.-A., Schlitzer, A., Chen, J., Ng, L.G., Wang, H., Liu, Zhiduo, $\mathrm{Su}, \mathrm{B}$., Ginhoux, F., 2019. Fate Mapping via Ms4a3-Expression History Traces Monocyte-Derived Cells. Cell 178, 1509-1525.e19. doi:10.1016/j.cell.2019.08.009

Ma, Y., Adjemian, S., Mattarollo, S.R., Yamazaki, T., Aymeric, L., Yang, H., Portela Catani, J.P., Hannani, D., Duret, H., Steegh, K., Martins, I., Schlemmer, F., Michaud, M., Kepp, O., Sukkurwala, A.Q., Menger, L., Vacchelli, E., Droin, N., Galluzzi, L., Krzysiek, R., Gordon, S., Taylor, P.R., Van Endert, P., Solary, E., Smyth, M.J., Zitvogel, L., Kroemer, G., 2013. Anticancer chemotherapy-induced intratumoral recruitment and differentiation of antigen-presenting cells. Immunity 38, 729-741. doi:10.1016/j.immuni.2013.03.003

MacDonald, K.P.A., Rowe, V., Bofinger, H.M., Thomas, R., Sasmono, T., Hume, D.A., Hill, G.R., 2005. The colony-stimulating factor 1 receptor is expressed on dendritic cells during differentiation and regulates their expansion. J. Immunol. 175, 1399-1405. doi:10.4049/jimmunol.175.3.1399

Meredith, M.M., Liu, K., Darrasse-Jeze, G., Kamphorst, A.O., Schreiber, H.A., Guermonprez, P., Idoyaga, J., Cheong, C., Yao, K.-H., Niec, R.E., Nussenzweig, M.C., 2012. Expression of the zinc finger transcription factor zDC (Zbtb46, Btbd4) defines the classical dendritic cell lineage. J. Exp. Med. 209, 1153-1165. doi:10.1084/jem.20112675

Min, J., Yang, D., Kim, M., Haam, K., Yoo, A., Choi, J.-H., Schraml, B.U., Kim, Y.S., Kim, D., Kang, S.-J., 2018. Inflammation induces two types of inflammatory dendritic cells in inflamed lymph nodes. Exp Mol Med 50, e458. doi:10.1038/emm.2017.292

Naik, S.H., Sathe, P., Park, H.-Y., Metcalf, D., Proietto, A.I., Dakic, A., Carotta, S., O’Keeffe, M., Bahlo, M., Papenfuss, A., Kwak, J.-Y., Wu, L., Shortman, K., 2007. Development of plasmacytoid and conventional dendritic cell subtypes from single precursor cells derived in vitro and in vivo. Nat. Immunol. 8, 1217-1226. doi:10.1038/ni1522

Nakano, H., Burgents, J.E., Nakano, K., Whitehead, G.S., Cheong, C., Bortner, C.D., Cook, D.N., 2013. Migratory properties of pulmonary dendritic cells are determined by their developmental lineage. Mucosal Immunol. 6, 678-691. doi:10.1038/mi.2012.106

Nakano, H., Lin, K.L., Yanagita, M., Charbonneau, C., Cook, D.N., Kakiuchi, T., Gunn, M.D., 2009. Blood-derived inflammatory dendritic cells in lymph nodes stimulate acute T helper type 1 immune responses. Nat. Immunol. 10, 394-402. doi:10.1038/ni.1707

Natsuaki, Y., Egawa, G., Nakamizo, S., Ono, S., Hanakawa, S., Okada, T., Kusuba, N., Otsuka, A., Kitoh, A., Honda, T., Nakajima, S., Tsuchiya, S., Sugimoto, Y., Ishii, K.J., Tsutsui, H., Yagita, H., Iwakura, Y., Kubo, M., Ng, L. guan, Hashimoto, T., Fuentes, J., Guttman-Yassky, E., Miyachi, Y., Kabashima, K., 2014. Perivascular leukocyte clusters are essential for efficient activation of effector T cells in the skin. Nat. Immunol. 15, 1064-1069. doi:10.1038/ni.2992

Odoardi, F., Kawakami, N., Klinkert, W.E.F., Wekerle, H., Flügel, A., 2007. Blood-borne soluble protein antigen intensifies $\mathrm{T}$ cell activation in autoimmune CNS lesions and 
exacerbates clinical disease. Proc. Natl. Acad. Sci. USA 104, 18625-18630. doi:10.1073/pnas.0705033104

Palframan, R.T., Jung, S., Cheng, G., Weninger, W., Luo, Y., Dorf, M., Littman, D.R., Rollins, B.J., Zweerink, H., Rot, A., von Andrian, U.H., 2001. Inflammatory chemokine transport and presentation in HEV: a remote control mechanism for monocyte recruitment to lymph nodes in inflamed tissues. J. Exp. Med. 194, 13611373. doi:10.1084/jem.194.9.1361

Plantinga, M., Guilliams, M., Vanheerswynghels, M., Deswarte, K., Branco-Madeira, F., Toussaint, W., Vanhoutte, L., Neyt, K., Killeen, N., Malissen, B., Hammad, H., Lambrecht, B.N., 2013. Conventional and monocyte-derived CD11b(+) dendritic cells initiate and maintain $\mathrm{T}$ helper 2 cell-mediated immunity to house dust mite allergen. Immunity 38, 322-335. doi:10.1016/j.immuni.2012.10.016

Salei, N., Rambichler, S., Salvermoser, J., Papaioannou, N.E., Schuchert, R., Pakalniškytè, D., Li, N., Marschner, J.A., Lichtnekert, J., Stremmel, C., Cernilogar, F.M., Salvermoser, M., Walzog, B., Straub, T., Schotta, G., Anders, H.-J., Schulz, C., Schraml, B.U., 2020. The Kidney Contains Ontogenetically Distinct Dendritic Cell and Macrophage Subtypes throughout Development That Differ in Their Inflammatory Properties. J. Am. Soc. Nephrol. doi:10.1681/ASN.2019040419

Satpathy, A.T., Briseño, C.G., Lee, J.S., Ng, D., Manieri, N.A., Kc, W., Wu, X., Thomas, S.R., Lee, W.-L., Turkoz, M., McDonald, K.G., Meredith, M.M., Song, C., Guidos, C.J., Newberry, R.D., Ouyang, W., Murphy, T.L., Stappenbeck, T.S., Gommerman, J.L., Nussenzweig, M.C., Colonna, M., Kopan, R., Murphy, K.M., 2013. Notch2dependent classical dendritic cells orchestrate intestinal immunity to attaching-andeffacing bacterial pathogens. Nat. Immunol. 14, 937-948. doi:10.1038/ni.2679

Satpathy, A.T., Kc, W., Albring, J.C., Edelson, B.T., Kretzer, N.M., Bhattacharya, D., Murphy, T.L., Murphy, K.M., 2012. Zbtb46 expression distinguishes classical dendritic cells and their committed progenitors from other immune lineages. J. Exp. Med. 209, 1135-1152. doi:10.1084/jem.20120030

Schraml, B.U., van Blijswijk, J., Zelenay, S., Whitney, P.G., Filby, A., Acton, S.E., Rogers, N.C., Moncaut, N., Carvajal, J.J., Reis e Sousa, C., 2013. Genetic tracing via DNGR-1 expression history defines dendritic cells as a hematopoietic lineage. Cell 154, 843858. doi:10.1016/j.cell.2013.07.014

Segura, E., Albiston, A.L., Wicks, I.P., Chai, S.Y., Villadangos, J.A., 2009. Different crosspresentation pathways in steady-state and inflammatory dendritic cells. Proc. Natl. Acad. Sci. USA 106, 20377-20381. doi:10.1073/pnas.0910295106

Serbina, N.V., Pamer, E.G., 2006. Monocyte emigration from bone marrow during bacterial infection requires signals mediated by chemokine receptor CCR2. Nat. Immunol. 7, 311-317. doi:10.1038/ni1309

Sharma, M.D., Rodriguez, P.C., Koehn, B.H., Baban, B., Cui, Y., Guo, G., Shimoda, M., Pacholczyk, R., Shi, H., Lee, E.-J., Xu, H., Johnson, T.S., He, Y., Mergoub, T., Venable, C., Bronte, V., Wolchok, J.D., Blazar, B.R., Munn, D.H., 2018. Activation of p53 in Immature Myeloid Precursor Cells Controls Differentiation into Ly6c+CD103+ Monocytic Antigen-Presenting Cells in Tumors. Immunity 48, 91-106.e6. doi:10.1016/j.immuni.2017.12.014

Tamoutounour, S., Guilliams, M., Montanana Sanchis, F., Liu, H., Terhorst, D., Malosse, C., Pollet, E., Ardouin, L., Luche, H., Sanchez, C., Dalod, M., Malissen, B., Henri, S., 2013. Origins and functional specialization of macrophages and of conventional and monocyte-derived dendritic cells in mouse skin. Immunity 39, 925-938. doi:10.1016/j.immuni.2013.10.004

Tsou, C.-L., Peters, W., Si, Y., Slaymaker, S., Aslanian, A.M., Weisberg, S.P., Mack, M., Charo, I.F., 2007. Critical roles for CCR2 and MCP-3 in monocyte mobilization from 
bone marrow and recruitment to inflammatory sites. J. Clin. Invest. 117, 902-909. doi:10.1172/JCI29919

Veres, T.Z., Kopcsányi, T., van Panhuys, N., Gerner, M.Y., Liu, Z., Rantakari, P., Dunkel, J., Miyasaka, M., Salmi, M., Jalkanen, S., Germain, R.N., 2017. Allergen-Induced CD4+ T Cell Cytokine Production within Airway Mucosal Dendritic Cell-T Cell Clusters Drives the Local Recruitment of Myeloid Effector Cells. J. Immunol. 198, 895-907. doi:10.4049/jimmunol.1601448

Villar, J., Segura, E., 2020. Decoding the heterogeneity of human dendritic cell subsets. Trends Immunol. 41, 1062-1071. doi:10.1016/j.it.2020.10.002

Wagner, C., Bonnardel, J., Da Silva, C., Spinelli, L., Portilla, C.A., Tomas, J., Lagier, M., Chasson, L., Masse, M., Dalod, M., Chollat-Namy, A., Gorvel, J.-P., Lelouard, H., 2020. Differentiation paths of peyer's patch lysodcs are linked to sampling site positioning, migration, and T cell priming. Cell Rep. 31, 107479. doi:10.1016/j.celrep.2020.03.043

Wakim, L.M., Waithman, J., van Rooijen, N., Heath, W.R., Carbone, F.R., 2008. Dendritic cell-induced memory T cell activation in nonlymphoid tissues. Science 319, 198-202. doi:10.1126/science.1151869

Zhuang, Q., Liu, Q., Divito, S.J., Zeng, Q., Yatim, K.M., Hughes, A.D., Rojas-Canales, D.M., Nakao, A., Shufesky, W.J., Williams, A.L., Humar, R., Hoffman, R.A., Shlomchik, W.D., Oberbarnscheidt, M.H., Lakkis, F.G., Morelli, A.E., 2016. Graft-infiltrating host dendritic cells play a key role in organ transplant rejection. Nat. Commun. 7, 12623. doi:10.1038/ncomms12623

Zigmond, E., Varol, C., Farache, J., Elmaliah, E., Satpathy, A.T., Friedlander, G., Mack, M., Shpigel, N., Boneca, I.G., Murphy, K.M., Shakhar, G., Halpern, Z., Jung, S., 2012. Ly6C hi monocytes in the inflamed colon give rise to proinflammatory effector cells and migratory antigen-presenting cells. Immunity 37, 1076-1090.

doi:10.1016/j.immuni.2012.08.026 